\title{
FUNERAL REFORM AND THE MATERIALITY OF DEATH IN THE RUSSIAN CIVIL WAR ***
}

\author{
Anastasia Papushina \\ Central European University, \\ Budapest, Hungary / Vienna, Austria
}

Based on documents produced by various Soviet institutions in Moscow, Ivanovo-Voznesensk, and Yaroslavl' in 1917-1922, this paper looks at the transformations of the Soviet funeral industry during the Civil War. After the October Revolution, a series of decrees proclaimed the secularization of funeral practices and attempted to purify them of monetary relations and hierarchy. The funeral ranks, or razryady, were eliminated, and Soviet institutions were obliged to provide equal services for all citizens regardless of their social background. This initiative was part of a larger project of creating a new man with new values by changing everyday practices. Due to administrative difficulties caused by the regime change and wartime challenges, the implementation of the funeral reform was fraught with perturbations at state, local, and family level. In Moscow, these problems led to the fullfledged "funeral crisis" of 1919, when the rise in mortality, serious shortages in supplies, and bureaucratic prevarications resulted in dead bodies being left unburied for prolonged periods of time. In the smaller towns of Ivanovo-Voznesensk and Yaroslavl', the crisis was less intense, and the funeral industry, while being transformed in accordance with the decrees, could still cope with popular demands. Several factors might explain this difference, including town size and the less rigid attitude of the provincial authorities to the implementation of funeral innovations. The ambitious funeral reform was not entirely successful: this paper argues that the attempts to change this death-related industry did not concern the fundamental norms of dealing with the dead, namely the idea shared by both the Soviet officials and the population that a dead body deserves personal space, privacy, and respect.

Keywords: Soviet Russia, Civil War, funeral reform, everyday norms, secularization, death-related practices

* The author would like to thank Marsha Siefert and Eszter Timar for their valuable input. This research was partially funded by the CEU Foundation.

** Citation: Papushina, A. (2021). Funeral Reform and the Materiality of Death in the Russian Civil War. In Quaestio Rossica. Vol. 9, № 1. P. 155-168. DOI 10.15826/qr.2021.1.571.

Цитирование: Papushina A. Funeral Reform and the Materiality of Death in the Russian Civil War // Quaestio Rossica. Vol. 9. 2021. № 1. P. 155-168. DOI 10.15826/ qr.2021.1.571.

(C) Papushina A., 2021

Quaestio Rossica • Vol. 9 • 2021 • № 1, p. 155-168 
В исследовании, выполненном на базе официальных источников из Москвы, Ярославля и Иваново-Вознесенска, рассматриваются изменения раннесоветской похоронной сферы в годы Гражданской войны. После Октябрьской революции ряд декретов секуляризовал похороны и сделал их формально бесплатными и равными для всех. Были упразднены разряды похорон, а советские учреждения, заменившие церковь, должны были обеспечить одинаковые минимальные условия похорон для всех категорий населения. Эта инициатива была частью более обширного проекта по созданию «нового человека» через внедрение новых повседневных практик. Однако в силу условий военного времени и административных сложностей, вызванных сменой режима, проведение похоронной реформы в жизнь было сопряжено с трудностями на государственном, местном и семейном уровнях. В Москве эти сложности вылились в так называемый «кладбищенский кризис» 1919 г. Тогда рост смертности, перебои с материалами и бюрократические проволочки привели к тому, что тела умерших в течение длительного времени оставались непогребенными. В маленьких городах (Иваново-Вознесенске и Ярославле) кризис был выражен слабее, и похоронная индустрия смогла справиться с запросами населения, несмотря на сложности, связанные с реформой, что объясняется размером населенных пунктов и менее пристальным вниманием провинциальных властей к проведению реформы. В статье утверждается, что попытки изменить погребальную сферу не затронули фундаментальных норм, касающихся обращения с покойными. В частности, представление о том, что покойнику необходимы собственное место, приватность и уважение, сохранялось как у населения, так и у советских служащих.

Ключевые слова: Советская Россия, Гражданская война, похоронная реформа, повседневные нормы, секуляризация, погребальные практики

On 16 January 1919, the legal department of the Moscow branch of the People's Commissariat of State Control initiated an inspection of city cemeteries after receiving alarming reports about "masses of unburied bodies

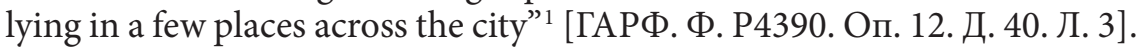
State controller Anatoly Yakubovich visited the mortuary of the Rzhevsky hospital to find about 150 unburied bodies "lying partly on shelves and partly right on the ground", "on one another across the entire barn area." [Там же. Л. 17]. Yakubovich was enraged (several words in his typewritten inspection report are thickly underlined in pencil): the picture he witnessed was a flagrant violation of norms related to the treatment of the dead. But in 1919, the case of Rzhevsky hospital was far from unique. In the Civil War years, the Soviet funeral industry in Moscow and, to a lesser extent, in the smaller cities of Central Russia found itself in an uneasy situation caused by regime change, funeral reform, and economic collapse against a background of ongoing military action.

\footnotetext{
${ }^{1}$ Translations of all documents are made by the author of the article.
} 
The political intention behind the funeral reform was to curtail the influence of the Church over everyday practices and to push forward a new way of living based on Marxist ideology and lay values. The reform and tough wartime conditions seem to have significantly transformed the way funerals were organized in Russia.

This research is based on typewritten and handwritten sources produced by various Soviet institutions. The sources include letters, minutes, reports from communal departments, inspection results, legislative documents and similar texts. While the Moscow archival holdings are quite well-known to scholars [Малышева; Sokolova], provincial cases often remain understudied, although they provide informative counterexamples to the situation in the capital ${ }^{2}$.

\section{The Funeral Reforms (1917-1918)}

Before 1917, Russian funerals were intrinsically bound to religion and were fundamentally hierarchical. When a person died, their family members were obliged to inform the local priest; without a religious ceremony, the funeral was not deemed to be legal [Булгаков, с. 1296-1301; see also: Сафонов]. Administratively, noting the fact in a church registry book was the only way to register a death. Economically, the Church was the major beneficiary and administrator of death-related funds. The priests performing the service received offerings from the families, and the cemetery clergy controlled the assets for maintaining cemetery plots: the land in the graveyards also belonged to the Church [Булгаков, с. 950-951]. The Church controlled formally independent funeral homes, which, in urban contexts, were the major providers of funeral accessories (clothes, shoes, flowers, and garlands) and arrangements (coffins, carriers, diggers, carts, and horses) [Sokolova, p. 252].

The funeral hierarchy lay at the intersection of economic and normative considerations. The scope of funeral arrangements correlated with the wealth and social status of the deceased. There were seven ranks, or razryady, of which the first was the most luxurious funeral service, while the seventh awaited those who could barely afford a coffin. Funeral ranks manifested themselves in the quality and quantity of funeral accessories, the scope of the procession, and the choice of the cemetery plot: the further away from the church or the entrance to the cemetery, the cheaper the places and the poorer the graves [Григорьев, с. 235-245; Засосов, Пызин, c. 45-48]. The cheapest funerals were sponsored by parish churches, mostly using funds collected from top-rank ceremonies.

These two foundational principles of pre-revolutionary Russian funerals were challenged in 1917. Vladimir Bonch-Bruevich called for a reform to separate church and state, resulting in the "civil marriage and the civil funeral that have long been awaited by all free-thinking people" [Бонч-

${ }^{2}$ I have been able to identify only a few works specifically concerning the provincial funeral industries and necropolises, among which [Панин; Миронова]. 
Бруевич, с. 13]. After the October Revolution, the Bolsheviks took a series of steps towards abolishing both the religious character of the funerals and their inequality. In December 1917, the decree "On civil marriage, children, and introducing civil act registration books," transferred the registration of death from the Church to newly organized lay bureaus [Собрание узаконений, с. 161-163]. About a month later, the decree "On the separation of church from state, and the school from the church" (January 23, 1918) secularized the public sphere and definitively deprived the Church of the right to register civil statuses, including deaths. Registry books were to be handed over to the bureaus for registering civil acts (organy zapisi aktov grazhdanskogo sostoyania, ZAGS) [Собрание узаконений, с. 849-858].

On 7 December 1918, the Council of People's Commissars issued a decree "On cemeteries and funerals." The decree transferred "all cemeteries, crematoriums, and morgues, as well as organizational aspects of funerals" to the local Soviets of Deputies (art. 1); introduced equal funerals for all citizens and eliminated the hierarchy of burial plots and funeral ceremonies, all while permitting families to organize church services at their own expense (art. 2); forbade paying for cemetery plots (art. 3); tied burials to formal permits from local ZAGS (art. 4); and municipalized funeral homes while obliging them to continue operations (art. 5) [Декрет о кладбищах и похоронах].

Following these reforms, the civil authorities were supposed to step in and take over the funeral procedures, replacing the Church, a responsibility they had never had before the revolution. Soviet officials were to supervise the administrative and material sides of funerals and ensure that all citizens received the same minimal service irrespective of their financial and social situation. Importantly, during the first post-revolutionary years, the Church was not eliminated from the equation: families were allowed to organize religious ceremonies if they wished. Families remained essential in the process: except for vulnerable social groups that the social security departments of the local Soviets catered for, it was the relatives of the deceased that initiated the process, paid for the funerals, and arranged for all the extras, ranging from the religious service to ceremonial accessories [Там же, ст. 6].

\section{Administrative Consequences of the Funeral Reforms}

In the absence of clear operational instructions, the ongoing redistribution of the death-related duties of the Church among Soviet institutions caused a visible administrative imbalance. For example, in Moscow, after being generally transferred from the Church to lay institutions, the registration of civil statuses was passed from local notary departments to the jurisdiction of the People's Commissariat for Internal Affairs [Кодекс законов об актах гражданского состояния; see also Галкин, с. 6]. The registration of deaths was accompanied by unfamiliar formalities. One should "make a note... in the legal department of the local Soviet of Deputies, and after that, petition the local commissariat to obtain a burial certificate." 
The certificate was necessary for contacting the cemetery committee in order to arrange a cemetery plot [ЦГАМО. Ф. 66. Оп. 12. Д. 682. Л. 21 об.]. Extensive bureaucracy made funerals an extremely time- and effort-consuming affair for families and authorities alike. According to an official report in 1919, the "registration of each individual death case was accompanied by needless bureaucratic formalities, the completion of which would hold back the very act of the interment of each particular body sometimes for weeks" [Там же].

Daily death-related activities were formally the responsibility of communal departments (kommunal'nye otdely): they were to control all "utility enterprises of local importance," including cemeteries, funeral bureaus, and crematoriums (to note, there were not any in Russia at the time). In Moscow, a specialized Department for Funeral and Sanitary Arrangements was established under the jurisdiction of the Moscow Soviet. The municipalization of Moscow funeral homes was intermittently controlled by the Economic Department of the Moscow Soviet and the Department of Social Security; the People's Commissariat for Public Health and the People's Commissariat for Internal Affairs sometimes made recommendations. Supplies for funerals - fabrics, wood, tools, accessories - were to be obtained at Prodotdel, Gorprodukt, Predrasmet, Tsentrotekstil', or some other centralized entity that redistributed nationalized or municipalized goods. The Department of Transport had to provide horses, carts, or trucks if requested [ЦГАМО. Ф. 66. Оп. 1. Д. 306. Л. 54; ГАРФ. Ф. Р4390. Оп. 12. Д. 40. Л. 37 об.]

In the provinces, the overlapping of responsibilities of different administrative bodies and the "dispersal of functions" of the communal department among other institutions was one of the reasons for the delayed implementation of the new death-related legislation. In the rapidly growing industrial town of Ivanovo-Voznesensk, $300 \mathrm{~km}$ north-east of Moscow, the funeral sub-sections were definitively attached to communal departments by a decree of the Council of People's Commissars as late as April 1920, while all other communal functions were united under the jurisdiction of a single department as late as the second half of 1922 [ГАИО. Ф. Р139. Оп. 1. Д. 40. Л. 45; ГАЯО. Ф. Р208. Оп. 1. Д. 23. Л. 1].

Other small towns managed to adapt faster. In Yaroslavl' $(270 \mathrm{~km}$ northeast of Moscow), the formal reorganization of the funeral industry took only a few months. In February 1919, a commission was elected at the Communal Department of the City Soviet to "urgently get to the organization of the funeral business" [ГАЯО Ф. Р122. Оп. 1. Д. 6. Л. 70]. Вy June, private funeral homes were municipalized, two new ones founded, and the whole business "ran strictly in the prescribed manner," providing the population with all the necessary services [ГАЯО. Ф. Р122. Оп. 1. Д. 119. Л. 14 об., 22 об., 28 об., 36].

As the exact order of distributing responsibilities was not prescribed, some funeral bureaus supervised both administrative and practical tasks. Upon receiving the death report from the notarial department, the newly organized bureaus in Yaroslavl' were responsible for issuing burial orders 
and work tickets for transportation and digging graves [ГАЯО. Ф. Р122. Оп. 1. Д. 133. Л. 97]. In the latter, they continued the business of older funeral homes, also selling funeral apparel, flowers, and other accessories. There was a somewhat similar consistency in operations in Ivanovo. In the winter of 1920, the Ivanovo communal department took formal control over the Consumer Society's business of making coffins and funeral accessories. Their distribution, however, remained the responsibility of the society [ГАИО. Ф. Р31. Оп. 1. Д. 193. Л. 31 об., 47].

It appears that with growing distance from the capital, funeral reforms gradually lost fervor. Moscow served as a testing ground for innovations, and the implementation of death-related decrees was controlled more attentively. Due to this heightened attention - and to the city's size - implementing novelties involved more competing actors and took more time [ЦГАМО. Ф. 66. Оп. 1. Д. 306. Л. 47]. In smaller towns, the funeral business tended to run as usual, just under a different name. Judging by the sources from Yaroslavl' and Ivanovo-Voznesensk, provincial authorities wanted to report the successful implementation of the reforms rather than push for fundamental changes in this domain. Popular demand for new procedures was also low: in Ivanovo, by March 1918, there was not a single case of a civil marriage, and the civil registration of deaths did not even come up in discussions [ГАИО. Ф. Р31. Оп. 1. Д. 52. Л. 2, 4, 4 об.]. Initiative usually came from the capital.

\section{War-Related Obstacles to the Funeral Reform}

Judging by the sources from Moscow, Yaroslavl', and Ivanovo-Voznesensk, the funeral industry in Central Russia would have been able to demonstrate at least superficial compliance with the new regulations relatively quickly. However, continuous military action and the associated circumstances complicated the implementation of the 1917-1918 funeral reforms. Russia had been at war since 1914; after signing the Treaty of Brest-Litovsk, fighting continued within the territory of the former Romanov Empire until at least 1922. During this period, one major consequence of the war for the funeral industry was a colossal rise in mortality. Due to the unreliable and incomplete statistical data, administrative issues related to the regime change, and methodological complications, the estimates of Russian death rates during these years vary greatly. Based on various estimates, the First World War, the Civil War, war-associated epidemics, and other diseases, as well as political executions and terror, might have taken 8 to 18 million lives ${ }^{3}$.

\footnotetext{
${ }^{3}$ The estimate of 8 million is given in [Гражданская война и иностранная интервенция в СССР, с. 14]. Boris Urlanis believes that in 1917-1920, the number of deaths accounted for 10-11 million [Урланис, c. 26]. Sergey Maksudov estimates that between 1913 and 1922, the Russian population lost about 15.5 million people, including those dead from 1921 famine [Максудов, с. 187]. Vadim Erlikhman, summarizing losses from the First World War, the Civil Wwa, political terror (about 2 million people), epidemics (about 5 million people), and emigration (about 2 million people), concludes that '“drect population losses in 1914-1922 account for 18.,5 million people" [Эрлихман, с. 12].
} 
In the cities and towns of Central Russia, it was not the fighting itself, but war-related diseases that took on the most menacing proportions. In winter, the main killers were typhus and diseases of the respiratory system: pneumonia, influenza, and the Spanish flu. In summer, the heat and humidity helped spread gastro-intestinal infections, cholera, and dysentery. The spread of infections was associated with social migrations. "It is known that typhus is brought to Moscow from the outside, and this time, epidemics are spread along the railroads, mostly by soldiers coming back from the front," Krasnaya Moskva wrote in 1920 [Красная Москва, с. 76]. In the overcrowded barracks of soldiers and war prisoners, infections were numerous and ever more threatening for civilian populations given that they were often situated within the city's reach. Permanent migrations of armies, refugees, and seasonal workers running to their native villages away from hunger and conscription helped to spread diseases out into the provinces. Hindered access to sanitation and medicine aggravated the situation and further increased mortality.

For the funeral industry, the rise in mortality was a major impact factor. It meant that an increasingly high number of bodies had to be buried, and due to migrations, many of those bodies belonged to people who had died away from home, not having their families to take care of them. The burdensome task of burial fell on the state administrations and institutions.

Conscription was another factor influencing the funeral industry. Military duty was among the major leaks of potential Soviet personnel that, along with desertion and agricultural mobility, caused in summer a significant backflow of men of peasant origin to their native villages. Still, the urban funeral process needed day laborers for basic tasks: digging graves, carrying bodies, driving funeral carts. The Soviet funeral institutions tried to protect their workers from military duty. Thus, in July 1919, the Moscow Department for Funeral and Sanitary Arrangements proclaimed funeral-related jobs "labor conscription," and asked the presidium of the Moscow Soviet to consider all staff members of the department "enlisted in the military." As such, they would be banned from leaving their jobs [ЦГАМО. Ф. 66. Оп. 12. Д. 682. Л. 53, 53 об.] $]^{4}$

Transportation issues also hit the funeral industry hard. Most horses and automobiles were mobilized for the war. The remaining animals, carts, and trucks either belonged to private owners - and therefore had to be rented at exorbitant prices - or were at the disposal of several Soviet institutions, which caused never-ending protractions and made the means of transportation almost inaccessible for funerals. The horses often suffered from malnutrition and poor living conditions. An inspection of the Mos-

${ }^{4}$ The lack of personnel was partly due to a popular disgust towards carrying dead bodies and digging graves. These types of jobs were considered dirty and sometimes dangerous, and the staff turnover was high even in less tense times. In 1919, the Yaroslavl" funeral bureau had only nine carriers, and it was "not possible to supplement the staff due to the unwillingness of candidates sent... by the Labor Exchange"” o take up the job [ГАЯО. Ф. Р122. Оп. 1. Д. 133. Л. 97]. 
cow funeral department's stable in winter 1919 showed that all eighteen horses were undernourished, and seven of them were sick with mange [ЦГАМО. Ф. 66. Оп. 12. Д. 682. Л. 8 об.].

Finally, the war demanded all material resources available, including wood, textiles, and ironware of all sorts. The remaining supplies were offered to several competing Soviet institutions, and the funeral sections of communal departments were not first on the list. As a result, the funeral industry had a serious shortage of coffins, nails, shrouds, shoes, and other accessories deemed necessary for a decent funeral.

These effects of war were felt in the capital as well as in the provinces. In Moscow, with epidemics following one another and death rates breaking records, the combination of wartime challenges and administrative novelties caused in 1919 what was referred to as "the funeral crisis." Day laborers were hard to find (they were either being conscripted into the army or fled the city). In an attempt to force them to stay, the Department for Funeral and Sanitary Arrangements decided that its employees were "working under combat conditions, and therefore any non-fulfilment by workers and employees of orders... should be considered a violation of combat discipline" [ЦГАМО. Ф. 66. Оп. 1. Д. 306. Л. 96 об.]. This measure did not help. Transportation caused major problems as well: horses were few, centralized institutions had nothing to offer, and when the Department for Funeral and Sanitary Arrangements tried, in the winter of 1919, to rent carts from private owners, it "incurred such fantastic expenditures that we had to renounce this idea the very next day" [ЦГАМО. Ф. 66. Оп. 12. Д. 682. Л. 28 об.].

Tools and materials, even shovels and nails, were in short supply. When the stocks of both the communal department and Gorprodukt ran out, tools were purchased from private sellers at exorbitant prices [ЦГАМО. Ф. 66. Оп. 1. Д. 306. Л. 54]. As for coffins, it suddenly turned out that they were not in stock in Moscow, and the necessary number could not be produced due to the "absence of the necessary workforce for making them" and the "shortage of materials, planks, nails for making them" [ГАРФ. Ф. Р4390. Оп. 12. Д. 40. Л. 24].

As a result, the city had no means to clothe, cover, transport, and bury its dead, although their number was increasing daily. Throughout 1919, unburied bodies "accumulated in hospitals, clinics, morgues, commissariats, and private apartments in such numbers that there appeared a serious threat to the public order regarding the health of the citizens of Moscow" [ЦГАМО. Ф. 66. Оп. 12. Д. 682. Л. 16]. Other bodies were buried, but scandalously: they arrived in cemeteries "in a disgraceful condition: naked, in horrible postures; they were put not only inside streetcar carriages but also on the platforms." At the cemeteries, they were laid to rest - often in communal graves (only tolerated in extreme conditions such as during war), often without coffins [ЦГАМО. Ф. 66. ОП. 12. Д. 682. Л. 25 об.; ГАРФ. Ф. Р4390. Оп. 12. Д. 40. Л. 32 об.]. Such disorder lasted in Moscow for over a year and only started to ease in mid to late 1920 . 
The smaller cities of Central Russia went through the Civil War period with lesser shocks, although not effortlessly. In Yaroslavl', wartime hardships hit the funeral industry in the same way as other branches of the communal economy. Horses were dying, men were leaving or unwilling to take on the unpleasant responsibilities in the burial process [ГАЯО. Ф. Р122. ОП. 1. Д. 119. Л. 14, 14 об.]. From December 1918 to April 1920, there were four increases in the costs of funeral services and in the price of "all accessories related to funerals," each time going up by 20 to 50 per cent [ГАЯО. Ф. Р122. Оп. 1. Д. 7. Л. 80 об., 189, 189 об.]. The variety of funeral accessories available in the warehouse of the communal department was scarce: the two bureaus, despite their alleged smooth functioning, could only offer mousseline for shrouds, as "there was nothing else." A special statement also admitted that "catafalques did not function due to the absence of horses" - but one could ask for a carrier to take the body to the cemetery [ГАЯО. Ф. P122. Оп. 1. Д. 133. Л. 9 об.]. Violations of burial norms were similar to those in Moscow but were infrequent. Thus, in March 1919, a squadron commander of a railroad defense regiment called the sanitary department's attention to the "inadmissible occurrences:" bodies taken to a cholera cemetery were not buried, but simply piled up "as if at a wood yard" [Там же. Л. 5]. Still, according to a report from late 1919, "the population was getting all the services they wanted," and the situation was far from critical. Importantly, after a short period of reorganization, individual artisans resumed their businesses, producing accessories for the deceased. The funeral department acted as their employer and as an intermediary between them and their clients [ГАЯО. Ф. Р208. Оп. 1. Д. 56; Ф. Р122. Оп. 1. Д. 214].

Similarly, in Ivanovo, the shortage of materials, manpower, and supplies was tangible in the communal department. The dirtiest work caused most problems: the sanitation brigade suffered from the loss of horses and "absence (crossed out) shortage of manpower and abse (crossed out) shortage of shoes for workers" [ГАИО. Ф. Р1175. ОП. 1. Д. 52а. Л. 4, 11]. Compared to this, the situation in the funeral department was regular. It generally "satisfied all citizens' requests for coffins," even though the coffin workshop was often "in urgent need of battens for making coffins and of upholsterer's sundries” [Там же]. A Moscow-like crisis did not happen.

\section{Monetary Relations, Hierarchy, and The Persistence of Older Norms}

It is clear that during an acute economic and political situation, the Soviet state proved unable to cope with the challenges in the funeral sphere it was partly responsible for. Taking control over cemeteries and municipalizing funeral supplies was not enough to respond to increased mortality and wartime scarcity; the cost of materials and services was ever-rising as private suppliers used the situation for their own benefit. State allocations for maintaining the funeral industry were close to nothing: as late as January 1919, the head of the Moscow Vagan'kovskoe Cemetery Workers' Committee explained that "the decree on nationalizing the funeral industry has 
not been implemented yet" because the cemetery did not receive any state funding [ГАРФ. Ф. Р4390. Оп. 12. Д. 40. Л. 30]. Funeral administrations were forced to spend increasingly high sums from their tight budgets on transportation, workers' remuneration, and supplies.

Consequently, institutions tried to share their responsibilities with the population, which seemed especially appropriate given the traditionally high level of family engagement in the funeral process. By the decrees of 1917 and 1918, families were allowed to organize extra services and arrangements at their own expense; in 1919-1920, they were also being forced to cover the basics that were supposed to come free of charge to all citizens. Cemetery management and funeral departments charged for their services, as this was often the only way to keep the business running and to ensure the provision of even the modest supplies they could offer. Cemetery committees continued the pre-revolutionary practice of selling grave plots, which was formally prohibited in 1919.

In such circumstances, feeble efforts to keep funerals free of charge or at least affordable - for instance, by exchanging payments for coupons that were then to be remunerated in cash at the social security department after the funeral ${ }^{5}$ - were doomed. Funerals remained a service to be purchased. This automatically brought back the hierarchy: some families could afford more sophisticated services (in more fortunate cases, this would cover the costs for burying the poorest) [ГАРФ. Ф. Р4390. ОП. 12. Д. 40. Л. 30]. For some, however, the financial barrier completely blocked off burials. This was one of the reasons for the emergence of the funeral crisis in Moscow: for the authorities and the population alike, the cost of funeral necessities was often unsurmountable. As one report pointed out, prices for carrying the body to the cemetery and digging the grave could be so high that the "horrified" relatives of the deceased, "unable to satisfy the appetites of cemetery bureaus and gravediggers due to the stringency in money, left the bodies of their relatives in the institutions where death had taken them" [ЦГАМО. Ф. 66. Оп. 12. Д. 682. Л. 22].

These critical situations, however, were never considered a new norm either by the Soviet authorities that condemned them in internal reports and letter exchanges or by the people, who, according to the official papers, openly expressed their discontent at the sight of a communal grave or an unburied body. Secularizing the funeral ritual was provocative, but the possibility of arranging a religious service privately mitigated the irritation. But a departure from the basic norms of dealing with the dead was intolerable.

Judging by the sources cited above, these norms were related to the privacy and decency of the dead body and its personal space. For the funeral to be considered proper, the deceased had to have specially made apparel and shoes, an individual coffin, and an individual grave. Communal graves were unwanted but tolerated in extreme situations. Crematoriums, although mentioned in the 1918 decree and different circular letters coming

\footnotetext{
${ }^{5}$ The scheme was discussed in: [ГАЯО. Ф. Р122. Оп. 1. Д. 133. Л. 3].
} 
to communal departments "from above," were rarely, if ever, seriously considered "on the ground." In Moscow, where the first debate about building a crematorium took place in 1919, the enterprise was considered not only too expensive, but "extremely harmful for the psychology" of the population, who could see the smoke coming up from its chimney [ЦГАМО. Ф. 66. Оп. 12. Д. 682. Л. 30 об.]. In Ivanovo and Yaroslavl', building a crematorium was never discussed during the period in question. The only way to deal with bodies was to lay them in the ground.

Cemetery grounds, even under the new Soviet management, were respected. While in Moscow there were suggestions that monastery cemeteries in the city center should be used for the "public good," such as rearranging them into children's playgrounds or public parks, these ideas often met with strong disapproval from the local population. In the provinces, I found no mention of reusing cemetery lands for civil purposes. On the contrary, the Soviet funeral institutions discussed building new fences and arranging the grounds so that the cemetery "looked proper," with pathways swept and monuments cleaned [ГАИО. Ф. Р139. ОП. 1. Д. 17. Л. 105].

The funeral reform of 1917 and 1918 brought ambiguous results. Excluding the Church from participation in the funeral process was the first step in the reform. Administratively, this was completed in the European part of Russia by the end of the Civil War: church registry books were passed to Soviet institutions, the population got used to new formalities. As for the ritual component, religion was pushed from the official sphere into the private realm, but it certainly did not disappear. Families of the deceased continued to arrange funeral liturgies and pay the priests for performing the funeral service well into the $1920 \mathrm{~s}^{6}$. It is also noteworthy that, a few years later, the Bolsheviks came up with a set of alternative rituals accompanying the funeral: it turned out that a purely pragmatic procedure felt wrong. These efforts were part of the polemics about "the new everyday" (novyj byt).

The role of Soviet institutions in the funeral industry was complex. Formally, the funeral departments in the framework of the communal departments of the local Soviets managed the process, and workers' committees replaced the clergy in cemetery management. After the initial difficulties, these institutions began to cope with the task. At the same time, the funeral departments often preferred to act as intermediaries between artisans, private bureaus, individual workers, and other independent suppliers, on the one hand, and the families of the deceased, on the other. The pre-revolutionary mechanics continued working, only now there was one more agent

${ }^{6}$ As late as 1925, the antireligious magazine Безбожник y станка (Atheist at the Workbench) criticized those - mostly older women - who continued to bring their last eggs and butter to the priests to pay them for funeral services. 
between the artisans and their clients. The funeral departments' staff could include former owners of funeral homes or other specialists in the area; under a different sign, they maintained their duties and responsibilities. This distribution of responsibilities makes one ask how innovative the changes to funerals were.

As for the principles introduced by the decree of 7 December 1918, they did not stand the test of wartime. The free-of-charge basis of funerals was the first to fall, despite repeated calls to preserve it. Given the near absence of state allocations for the industry, local authorities had to manage on their own, thus quickly reintroducing costs for their services. The elimination of the free service brought back the inequality of funerals.

In maneuvering between ideology, norms, and the material considerations of the moment, the latter often prevailed, but when it came to violation of fundamental death-related norms - such as leaving bodies unburied or burying them without a proper coffin in a communal grave - these norms were never questioned. Rather, the population and Soviet officials regarded these cases as abnormalities that had to be eliminated for the situation to come back to normal, not to continue in a new materialist direction.

The role of families in the funeral procedure remained essential. The public authorities strongly counted on the participation of families; otherwise, the system was prone to collapse, as the Moscow example showed. In the absence of those personally involved in the funeral procedure, and under the severe pressure of socioeconomic hardships, centralized Soviet institutions were likely to choose pragmatic considerations over ethical ones. The violation of death-related norms was strongly felt, and when the wartime crisis was over, the norms were restored.

\section{Список литературы}

Бонч-Бруевич В. Отделение церкви от государства // Деятели Октября о религии и церкви. М. : Мысль, 1968. С. 12-13.

Булгаков С. Настольная книга для священно-церковно-служителей. 3-е изд., испр. и доп. Киев : Тип. Киево-Печер. Успен. лавры, 1913. 1772 с.

ГАИО. Ф. Р31. Оп. 1. Д. 52, 193; Ф. Р139. Оп. 1. Д. 17, 40; Ф. Р1175. Оп. 1. Д. 52а.

ГАРФ. Ф. Р4390. Оп. 12. Д. 40.

ГАЯО. Ф. Р122. Оп. 1. Д. 6, 7, 119, 133, 214; Ф. Р208. Оп. 1. Д. 23, 56.

Галкин М. Акты состояний (продолжение). Новое законодательство и сообщения с мест // Революция и церковь. 1919. № 2. С. 5-9. $704 \mathrm{c}$.

Гражданская война и иностранная интервенция в СССР. М. : Сов. энцикл., 1983.

Григорьев М. А. Петербург 1910-х годов : Прогулки в прошлое. СПб. : Рос. ин-т истории искусств, 2005. 280 с.

Декрет о кладбищах и похоронах. От 7 декабря 1918 года // Библиотека нормативно-правовых актов СCCP : [сайт]. URL: http://www.libussr.ru/doc_ussr/ussr_414.htm (дата обращения: 01.05.2020).

Засосов Д. А., Пызин В. И. Повседневная жизнь Петербурга на рубеже XIXXX веков. М. : Молодая гвардия, 2003. 480 с.

Кодекс законов об актах гражданского состояния, брачном, семейном и опекунском праве // Исторические материалы : [сайт]. URL: http://istmat.info/node/31624 (дата обращения: 01.05.2020). 
Красная Москва, 1917-1920 гг. М. : Гос. образцовая тип. (бывш. т-ва И. Д. Сытина), $1920.380 \mathrm{c}$.

Максудов С. Потери населения СССР. Benson, Vermont : Chalidze Publ., 1989. 298 c.

Мальшева С. «На миру красна» : Инструментализация смерти в Советской России. М. : Новый хронограф, 2019. 464 с.

Миронова E. В. Архангельское кладбище Казани: опыт исторического исследования // Ист. этнология. Т. 3. 2018. № 1. C. 137-148. DOI 10.22378/he.2018-3-1.137-148.

Панин А. С. Городская повседневность после 1917 года по материалам Тульского некрополя // История. Историки. Источники. 2017. № 2. С. 48-65.

Сафонов А. Указ 17 апреля 1905 г. «Об укреплении начал веротерпимости» в контексте формирования института свободы совести в законодательстве Российской империи // История и современность: белорусская государственность в восточноевропейском цивилизационном контексте : сб. науч. работ, посв. 90-летию со дня рожд. проф. И. А. Юхо. Минск : Бизнесофсет, 2012. С. 337-344.

Собрание узаконений и распоряжений правительства за 1917-1918 г. М. : Управление делами Совнаркома СССР, 1942. 1483 с.

Урланис Б. Динамика населения СССР за 50 лет // Население и народное благосостояние. М. : МЕСИ, 1968. С. 20-43.

ЦГАМО. Ф. 66. Оп. 1. Д. 306; Оп. 12. Д. 682.

Эрлихман В. В. Потери народонаселения в XX веке : справочник. М. : Рус. панорама, 2004. $175 \mathrm{c}$.

Sokolova A. Soviet Funeral Services: From Moral Economy to Social Welfare and Back // Revolutionary Russia. Vol. 32. 2019. № 2. P. 251-271. DOI 10.1080/09546545.2019.1687188.

\section{References}

Bonch-Bruevich, V. (1968). Otdelenie tserkvi ot gosudarstva [Separation of Church and State]. In Deyateli Oktyabrya o religii i tserkvi. Moscow, Mysl', pp. 12-13.

Bulgakov, S (1913). Nastol'naya kniga dlya svyashchenno-tserkovno-sluzhitelei [A Handbook for Priests]. $3^{\text {rd }}$ Ed., new and update. Kiev, Tipografiya Kievo-Pecherskoi Uspenskoi lavry. $1772 \mathrm{p}$.

Dekret o kladbishchakh i pokhoronakh ot 7 dekabrya [Decree on Cemeteries and Funerals. December 7]. (1918). In Biblioteka normativno-pravovykh aktov SSSR [website]. URL: http://www.libussr.ru/doc_ussr/ussr_414.htm (accessed: 01.05. 2020).

Erlichman, V. V. (2004). Poteri narodonaseleniya v XX veke. Spravochnik [Population Losses in the $20^{\text {th }}$ Century. A Handbook]. Moscow, Russkaya panorama. $175 \mathrm{p}$.

GAIO [State Archive of Ivanovo Region]. Stock R31. List 1. Dos. 52, 193; Stock R139. List 1. Dos. 17, 40; Stock R1175. List 1. Dos. 52a.

Galkin, M. (1919). Akty sostoyanii (prodolzhenie). Novoe zakonodatel'stvo i soobshcheniya s mest [Acts of Statuses. (Continuation). New Legislation and Messages from the Field]. In Revolyutsiya i tserkov'. No. 2, pp. 5-9.

GARF [State Archive of the Russian Federation]. Stock R4390. List 12. Dos. 40.

GAYAO [State Archive of Yaroslavl' Region]. Stock R122. List 1. Dos. 6, 7, 119, 133, 214; Stock R208. List. 1. Dos. 23, 56.

Grazhdanskaya voina i inostrannaya interventsiya v SSSR [Civil War and Foreign Intervention in the USSR]. (1983). Moscow, Sovetskaya entsiklopediya. 704 p.

Grigor'ev, M. A. (2005). Peterburg 1910-kh godov. Progulki v proshloe [Petersburg in the 1910s. Walks into the Past]. St Petersburg, Rossiiskii institut istorii iskusstv. 280 p.

Kodeks zakonov ob aktakh grazhdanskogo sostoyaniya, brachnom, semeinom i opekunskom prave [Code of Regulations Regarding Civil Statuses, Marital Law, Family Law, and Tutelage]. (N. d.). In Istoricheskie materialy [website]. URL: http://istmat.info/ node/31624 (accessed: 01.05.2020).

Krasnaya Moskva, 1917-1920 gg. [Red Moscow, 1917-1920]. (1920). Moscow, Gosudarstvennaya obraztsovaya tipografiya (byvshaya tovarishchestva I. D. Sytina). 380 p. 
Maksudov, S. (1989). Poteri naseleniya SSSR [Population Losses in the USSR]. Benson, Vermont, Chalidze Publ. 298 p.

Malysheva, S. (2019). "Na miru krasna". Instrumentalizatsiya smerti v Sovetskoi Rossii [Make Less Trouble. The Instrumentalisation of Death in Soviet Russia]. Moscow, Novyi khronograf. $464 \mathrm{p}$.

Mironova, E. V. (2018). Arkhangel'skoe kladbishche Kazani: opyt istoricheskogo issledovaniya [The Kazan Arkhangel'skoye Cemetery: An Essay on History]. In Istoricheskaya etnologiya. Vol. 3. No. 1, pp. 137-148. DOI 10.22378/he.2018-3-1.137-148.

Panin, A. (2017). Gorodskaya povsednevnost' posle 1917 goda po materialam Tul'skogo nekropolya [Post-1917 Everyday Town Life according to Materials from the Tula Town Necropolis]. In Istoriya. Istoriki. Istochniki. No. 2, pp. 48-65.

Safonov, A. (2012). Ukaz 17 aprelya 1905 g. "Ob ukreplenii nachal veroterpimosti" v kontekste formirovaniya instituta svobody sovesti v zakonodatel'stve Rossiiskoi imperii [Edict from 17 April 1905 On Strengthening the Foundations of Religious Tolerance in the Context of Forming the Institution of Freedom of Conscience in the Legislation of the Russian Empire]. In Istoriya i sovremennost': belorusskaya gosudarstvennost'v vostochnoevropeiskom tsivilizatsionnom kontekste. Sbornik nauchnykh rabot, posvyashchennykh 90-letiyu so dnya rozhdeniya professora I. A. Yukho. Minsk, Biznesofset, pp. 337-344.

Sobranie uzakonenii i rasporyazhenii pravitel'stva za 1917-1918 g. [Code of Regulations of the Government, 1917-1918] (1942). Moscow, Upravlenie delami Sovnarkoma SSSR. 1483 p.

Sokolova, A. (2019). Soviet Funeral Services: From Moral Economy to Social Welfare and Back. In Revolutionary Russia. Vol. 32. No. 2, pp. 251-271. DOI 10.1080/09546545.2019.1687188.

Ts GAMO [Central State Archive of the Moscow Region]. Stock 66. List 1. Dos. 306; List 12. Dos. 682.

Urlanis, B. (1968). Dinamika naseleniya SSSR za 50 let [USSR Population Dynamics over 50 years]. In Naselenie i narodnoe blagosostoyanie. Moscow, MESI, pp. 20-43.

Zasosov, D. A, Pyzin, V. I. (2003). Povsednevnaya zhizn' Peterburga na rubezhe XIX$X X$ vekov [Everyday Life in Petersburg at the Turn of the $20^{\text {th }}$ Century]. Moscow, Molodaya gvardiya. $480 \mathrm{p}$.

The article was submitted on 29.06.2020 